\title{
Connected to TV series: Quantifying series watching engagement
}

\author{
ISTVÁN TÓTH-KIRÁLY ${ }^{1,2 *}$, BEÁTA BŐTHE ${ }^{1,2}$, ESZTER TÓTH-FÁBER ${ }^{2}$, GYŐZŐ HÁGA² and GÁBOR OROSZ ${ }^{2,3}$ \\ ${ }^{1}$ Doctoral School of Psychology, ELTE Eötvös Loránd University, Budapest, Hungary \\ ${ }^{2}$ Institute of Psychology, ELTE Eötvös Loránd University, Budapest, Hungary \\ ${ }^{3}$ Institute of Cognitive Neuroscience and Psychology, Research Centre for Natural Sciences, Hungarian Academy \\ of Sciences, Budapest, Hungary
}

(Received: April 3, 2017; revised manuscript received: September 10, 2017; accepted: December 3, 2017)

\begin{abstract}
Background and aims: Television series watching stepped into a new golden age with the appearance of online series. Being highly involved in series could potentially lead to negative outcomes, but the distinction between highly engaged and problematic viewers should be distinguished. As no appropriate measure is available for identifying such differences, a short and valid measure was constructed in a multistudy investigation: the Series Watching Engagement Scale (SWES). Methods: In Study $1\left(N_{\text {Sample } 1}=740\right.$ and $\left.N_{\text {Sample } 2}=740\right)$, exploratory structural equation modeling and confirmatory factor analysis were used to identify the most important facets of series watching engagement. In Study $2(N=944)$, measurement invariance of the SWES was investigated between males and females. In Study $3(N=1,520)$, latent profile analysis (LPA) was conducted to identify subgroups of viewers. Results: Five factors of engagement were identified in Study 1 that are of major relevance: persistence, identification, social interaction, overuse, and self-development. Study 2 supported the high levels of equivalence between males and females. In Study 3, three groups of viewers (low-, medium-, and high-engagement viewers) were identified. The highly engaged at-risk group can be differentiated from the other two along key variables of watching time and personality. Discussion: The present findings support the overall validity, reliability, and usefulness of the SWES and the results of the LPA showed that it might be useful to identify at-risk viewers before the development of problematic use.
\end{abstract}

Keywords: exploratory structural equation modeling (ESEM), latent profile analysis (LPA), problematic use, series watching engagement, Series Watching Engagement Scale (SWES), TV series watching

\section{INTRODUCTION}

Television watching is one of the most dominant leisure time activities in the world. According to the 2014 American Time Use Survey (US Department of Labor, 2015), the average time spent watching television was $2.8 \mathrm{hr}$ on an average day, which accounts for more than half of the viewers' leisure time. Similar watching times were also reported in Canada (Statistics Canada, 2011), New Zealand (Statistics New Zealand, 2011), or the United Kingdom (Lader, Short, \& Gershuny, 2006). Based on the data from more than 20 countries, television watching reportedly took up about $12-16 \mathrm{hr}$ on an average week (Fisher \& Robinson, 2011). However, television is not the only source of content watching. Pontes, Szabó, and Griffiths (2015) found that among the most preferred work-unrelated activities, watching videos and films was the fourth most popular - being mentioned by more than one third of the respondents - along with browsing general information, using social networks, e-mails, and online chatting services. Based on the data of the Pew Research Center, the percentage of Internet-using adults watching movies or series has doubled over the course of 2 years, from $16 \%$ to $32 \%$, respectively (Purcell, 2010). On the basis of these results, it can be supposed that series watching takes up increasingly larger and larger portions of this activity.

TV series can be defined as a set of programs that are regularly presented with the same characters, themes, or subjects (Series, n.d.). The storyline revolving around the characters is usually split into episodes with fixed length; these episodes then add up to seasons, which can span across years. What can differentiate series watching from television viewing? Series watching and television watching are two distinct categories: whereas the concept of "series watching" refers to the content of the activity, "television watching" mainly alludes to the medium or device through which the activity itself occurs. Another essential aspect of series watching is that this activity can be performed though any types of screens. The main focus of this concept is the activity itself, not the device though which it occurs.

Why series watching as a research topic might be important? The new era of series watching is different from its antecedents for the following reasons: first of all, series

\footnotetext{
* Corresponding author: István Tóth-Király; Institute of Psychology, ELTE Eötvös Loránd University, Izabella utca 46, Budapest H-1064, Hungary; Phone: +36 20582 9949; E-mails: tothkiralyistvan@gmail. com; toth-kiraly.istvan@ppk.elte.hu
} 
can either be downloaded or streamed via legal or illegal means that allows watching several episodes in line. However, previously, the viewer had to wait for the new episode 1 day or even 1 week. Second, as broadband Internet has become widely available all around the world, almost everyone can access series. Previously, the given series was not immediately available for the international audience and if someone wanted to watch it, there was often a language barrier and it was not easily accessible, only through specific channels. Now, series can be watched practically anywhere and anytime. Previously, series were watched in front of the television during a certain period of the day. Finally, there is an abundance of series that we can choose from. Previously, viewers could only choose from a limited amount of series.

How is it possible that the television-viewing time is decreasing, but series watching has a renaissance? In this new era, the phenomenon of cord cutting - referring to the process of cancelling traditional television subscriptions in favor of alternative, Internet-based services (Cord Cutting, n.d.) - has been becoming increasingly prevalent, as it has been reported by multiple media outlets and journals (e.g., Heisler, 2015; Lisanti, 2012; Magid, 2013). As a result of cord cutting, the usage patterns and preferences of viewers can vastly differ. The aforementioned characteristics of series watching provide much more autonomy to the viewer: they are free to choose where, when, how, how much, and what they want to watch. In addition to these characteristics, there are three further reasons as to why series watching is popular nowadays. Downloading or streaming is free or relatively cheap as viewers only have to pay for Internet access - and automatic monthly subscription, if they were to consume series using legal means instead of illegal downloading. Almost no effort is needed to watch series; it is a relatively passive activity. In addition, viewers can almost certainly find a show that fits their interest, because series have a high variety with different themes, length, and topics. Finally, series are created to be enjoyable and episodes often end with a cliffhanger, which further motivates the viewer to continue watching.

In the new, online era, to what extent do people watch series? As one of the major streaming services companies, Netflix has 62 million viewers in over 50 countries who watch more than 10 billion $\mathrm{hr} /$ month, which on average is 93 min per user every day (Smith, 2015). Seventy-six percent of their viewers considered watching multiple episodes of a great TV show as a refuge from their usually busy lives (PR Newswire, 2013). Nearly 50\% of the young adults watch Netflix on their mobile devices, rather than on PC (Lella, 2014). In 2016, Netflix has announced that its webbased services became available in almost 200 countries around the world (Netflix Media Center, 2016). With this announcement, the company made it possible to watch series and TV shows on devices with Internet connection, gathering an even higher number of monthly subscribers in these yet unexplored countries. Although it is difficult to measure illegal downloading or streaming, viewers heavily use these options as several unofficial file-sharing and streaming services can be found among the top 500 most visited websites globally (Alexa.com, 2016). These numbers indicate that a huge number of viewers are highly involved in series watching.

Although the field of series watching is relatively unexplored, it can be hypothesized that this overinvolvement could become problematic that in turn could lead to negative, maladaptive outcomes. Based on previous studies on other screen-based activities (e.g., problematic Internet use, problematic online gaming, and problematic social media use), intense screen-time is related to higher levels of anxiety (Mentzoni et al., 2011), depression (Bélanger, Akre, Berchtold, \& Michaud, 2011; Yau, Potenza, \& White, 2013), loneliness (Ang, Chong, Chye, \& Huan, 2012; Lemmens, Valkenburg, \& Peter, 2011), low well-being (Van der Aa et al., 2009), low self-esteem (Wang et al., 2013), poorer self-control and higher levels of impulsivity (Mazhari, 2012; Yau et al., 2013), problems related to sleeping (Do, Shin, Bautista, \& Foo, 2013), poorer physical health (Kelley \& Gruber, 2010, 2013), decreased academic achievements (Brunborg, Mentzoni, \& Frøyland, 2014; Skoric, Teo, \& Neo, 2009), and other psychiatric conditions (Andreassen et al., 2016; Bernardi \& Pallanti, 2009; Kuss, Griffiths, Karila, \& Billieux, 2014; Starcevic, Berle, Porter, $\&$ Fenech, 2011). However, these problematic behaviors and outcomes stemming from overinvolvement only affect a small number of the population. It may be assumed that watching series for hours every day can become problematic, but this extensive watching may not interfere with other aspects of life. Also, generalizing pathological models to the non-pathological population is often misleading and erroneous (Billieux, Schimmenti, Khazaal, Maurage, \& Heeren, 2015). Consequently, what could be said about the majority who watch series on a regular basis without any problems? How could we describe their high involvement? One of the potential answers could be the concept of engagement.

\section{Defining series watching engagement}

Before series, soap operas - which can be described as a radio or television program in which the lives of recurring characters or groups are shown; also, the stories about their lives are more or less repetitive (Soap Opera, n.d.) - were in the center of research in the 1980s and 1990s with the main focus being on the motivations behind this activity (e.g., Alexander, 1985; Babrow, 1987; Carveth \& Alexander, 1985; Compesi, 1980; Greenberg, Neuendorf, Rothfuss, \& Henderson, 1982; Livingstone, 1988; Perse, 1986; Perse \& Rubin, 1990; Rubin, 1985). Simultaneously, a smaller proportion of the research focused on understanding the connectedness between the viewer and activity of series watching. This connectedness can be described by the concept of series watching engagement.

As a result of being on the periphery of research, several similar conceptualizations of engagement have been utilized in relation to soap operas. The first one was affinity that described the degree of importance television or soap operas had in the viewer's life (Greenberg, 1974 as cited in Perse, 1986; Rubin, 1977, 1979). Another concept was involvement that had several definitions. It has been described as the level of identification or perceived connection with the characters and the content (Levy \& Windahl, 1985 as cited in Godlewski \& Perse, 2010; Whetmore \& Kielwasser, 
1983). According to Greenberg et al. (1982), involvement was the emotional response of the viewers to the events in the soap opera. Perse (1990) referred it as an indication of personal engagement with the content along four dimensions: intentionality of watching, attention to the content, distraction during viewing, and elaboration of the content. Finally, Demir and Demir (2013) referred to it as connectedness, which is defined as the relationship between the viewer and series watching. They proposed that connectedness not only covers viewing time, but it is also related to the magnitude of series integrated to the self.

If we broaden our scope, we can see that the concept of engagement has been investigated in relation to online gaming. Charlton (2002) was among the first to suggest that the high degree of gaming engagement might be positive and non-interfering for many viewers. Many of the subsequent studies (Brunborg et al., 2013, 2014; Charlton \& Danforth, 2007, 2010; Ferguson, Coulson, \& Barnett, 2011) examined the connection of gaming engagement and problematic use (or addiction) and concluded that these two concepts are qualitatively different phenomena and should be distinguished from each other. First, as high engagement suggested to be related to the peripheral addiction criteria, it can only be considered as a potential precursor for problematic use, which fulfilled the core addiction criteria. Second, problematic use was often related to negative health-related outcomes (such as the ones mentioned above), but high engagement was not necessarily associated with health problems. A similar proposition has been suggested by Andreassen (2015) in the field of social network sites.

Apart from online gaming, another area where engagement has scientifically been examined is Facebook use (Ellison, Steinfield, \& Lampe, 2007). Although the concept of Facebook intensity has a different label, it is the same concept as engagement. In addition, this unidimensional construct has been previously expanded with both problematic and non-problematic aspects (Orosz, Tóth-Király, \& Bőthe, 2016), suggesting that engagement might incorporate aspects that can be related to both supposedly positive and supposedly negative outcomes, similarly to Charlton and Danforth $(2007,2010)$ and Brunborg et al. (2013, 2014).

\section{Overview of the present research}

Based on these previous studies on engagement, the present research was guided by the following question: how could we measure those viewers who are highly engaged, but not problematic? If engagement can be considered as a potential precursor of problematic use, then these highly engaged viewers can be considered as an at-risk group and identifying these viewers might be beneficial, because the development of problematic use could be prevented. Therefore, in the following studies, the main goal was the creation of a series watching engagement measure that was (a) short, (b) had adequate psychometric properties, and (c) can measure problematic and non-problematic aspects as well.

For this purpose, a three-study research was carried out. In Study 1, the process of item construction was performed and then exploratory structural equation modeling (ESEM) was used to establish the main dimensions of series watching engagement (Study 1a) and confirmatory factor analysis (CFA) was conducted for the purpose of cross-validation (Study 1b). In Study 2, tests of measurement invariance were carried out to investigate the generalizability of the construct of series watching engagement. In Study 3, latent profile analysis (LPA) was used to identify potential at-risk subcategories based on series watching engagement and to compare these groups along relevant variables.

\section{STUDY 1 - THE DEVELOPMENT OF THE SERIES WATCHING ENGAGEMENT SCALE (SWES)}

The first aim of this study was to create items for the SWES, which were able to measure the most important problematic and non-problematic aspects of series watching. The second aim was to create a scale, which was short and had good psychometric properties in terms of validity, reliability, and internal consistency.

\section{METHODS}

\section{Item construction}

To identify the most important aspects of series watching engagement, a focus group of 19 university students (4 males, 15 females, $M_{\text {age }}=20.11 ; S D_{\text {age }}=1.55$ ) who watch series at least once a week was created and met for multiple sessions. In order for them to more precisely grasp the concept of engagement, first they produced word associations regarding series watching, then they individually wrote about their connectedness to this activity. To minimize group decision-making biases, an iterative approach was applied: members first discussed their thoughts in pairs and then in smaller groups. During this part of the item creation, they could complement their previous responses on the basis of their discussions. These responses were gathered and integrated. At the end of these first sessions, the hypothesized factors of series watching engagement were established. In the second part of the sessions, the items were created by the members of the focus group. Their goal was to create items that were (a) close to the everyday language used for talking about series; (b) easy to understand; (c) concise; (d) clearly belonged to the given dimension, but not to the others; (e) were not double-barreled; (f) were not suggestive; and (g) were adjusted to the scaling. As a result of this procedure, a total of 31 items were created, which made up the initial pool.

\section{Procedure}

This study was conducted using an online questionnaire system, filling out took approximately $12 \mathrm{~min}$. The data collection occurred in June 2015 with the help of a Facebook page whose main profile is providing news and information about series. Participants were first informed about the aims and the content of the study. They were assured of their anonymity and the confidentiality of their answers. They had to check a box if they were inclined to 
participate. The first part of the questionnaire contained the 31 items of the SWES. In the second part, questions regarding demographic data were asked, such as gender, age, level of education, and relationship status. A total number of 1,511 respondents started to fill the questionnaires, but 22 of them did not agree to take part in the research and 9 respondents were excluded due to improper answers or being under 18 . Therefore, for the data analysis, we used the responses of 1,480 (male $=412$ and female $=$ $1,068)$ respondents. This sample was then divided into two subsamples with equal number of respondents and equal gender ratio. The first sample was used in Study 1a and the second sample in Study $1 \mathrm{~b}$ for the CFA for cross-validation.

\section{Participants}

Sample 1. This sample consisted of 740 Hungarian participants (female $=534 ; 72.2 \%$ ) between the ages of 18 and 74 years $\left(M_{\mathrm{age}}=28.57\right.$ years; $S D_{\mathrm{age}}=9.10$ years $)$. Among them, 299 of the participants $(40.4 \%)$ lived in the capital, $163(22.0 \%)$ in county towns, $200(27.0 \%)$ in towns, and 78 $(10.5 \%)$ in villages. Regarding their level of education, 47 $(6.4 \%)$ had primary school degree, 388 (52.4\%) had a high-school degree, and $305(41.2 \%)$ of them had a degree in higher education (bachelor, masters, or doctoral).

Sample 2. The cross-validation sample consisted of 740 Hungarian participants (female $=534 ; 72.2 \%$ ) between the ages of 18 and 67 years $\left(M_{\mathrm{age}}=25.73\right.$ years; $S D_{\mathrm{age}}=$ 7.80 years). A total of 366 of them (45.4\%) lived in the capital, $148(20.0 \%)$ in county towns, $173(23.4 \%)$ in towns, and $83(11.2 \%)$ in villages. Regarding their level of education, $43(5.8 \%)$ had primary school degree, $438(59.2 \%)$ had a high-school degree, and 259 (35.0\%) of them had a degree in higher education (bachelor, masters, or doctoral).

\section{Measures}

The initial version of the SWES contained a pool of 31 items, which were detailed in the Item Construction sections. Participants had to respond using a 7-point scale $(1=$ not true to me at all and $7=$ completely true to me).

\section{Statistical analysis}

For the statistical analyses, SPSS 22 and Mplus 7.3 (Muthén \& Muthén, 1998-2015) were used. The initial version of the SWES consisted of 31 items. Similar to Fahlman, MercerLynn, Flora, and Eastwood (2013), and Orosz, Tóth-Király, et al. (2016), each of the items was examined based on three criteria: (a) corrected item-total correlation, (b) normality in terms of skewness and kurtosis, and (c) content validity (Haynes, Richard, \& Kubany, 1995) compared with the other items and series watching in general.

In the next part, ESEM was performed on the rest of the items using Mplus with the oblique Geomin rotation and robust maximum-likelihood estimation as the data did not have multivariate normal distribution. ESEM is a modeling approach that incorporates both exploratory factor analysis (EFA) and structural equation modeling as it allows both the exploratory testing of alternative factor structures and cross-loadings of items. Furthermore, it can directly be compared with EFA and CFA as well (Asparouhov \& Muthén, 2009; Marsh, Morin, Parker, \& Kaur, 2014). Our initial findings were then cross-validated on the second sample with CFA. Compared with ESEM, CFA can be considered as a more restrictive method, because items are usually allowed to load on only one factor, while having their loadings on other factors constrained to zero (TóthKirály, Bőthe, \& Orosz, 2017; Tóth-Király, Orosz, et al., 2017). For this purpose, CFA was used to assess whether the factor structure of the SWES still had adequate fit with this more restrictive analytic process. To compare the models of Studies $1 \mathrm{a}$ and $1 \mathrm{~b}$, the profile similarity index (PSI) was calculated (Marsh et al., 2010). With this method, the similarity of the factor loadings can be evaluated throughout the two statistical procedures (in the present case, ESEM and CFA). It can be computed by correlating the standardized factor loadings of the two procedures with each other.

In addition, the first-order and the second-order CFA models were compared with the target coefficient $(\mathrm{T})$ of Marsh and Hocevar (1985). This coefficient was calculated by dividing the $\chi^{2}$ value of the first-order model with the $\chi^{2}$ value of the second-order model. It can have a maximum value of one with higher numbers suggesting that a secondorder factor (in the present case, series watching engagement) can adequately explain the covariance between the first-order factors. A target coefficient greater than 0.90 would support this hypothesis.

As the $\chi^{2}$ test is sensitive to sample size and minor model misspecifications, three typical goodness-of-fit indices were examined: the comparative fit index (CFI), the Tucker-Lewis Index (TLI), and the root mean square error of approximation (RMSEA). By following common interpretation guidelines (Hu \& Bentler, 1999; Marsh, Hau, \& Grayson, 2005), values greater than 0.90 and 0.95 for the CFI and TLI indicate adequate or excellent fit, whereas values smaller than 0.08 and 0.06 for the RMSEA can be considered adequate or excellent model fit. Internal consistency was measured by Cronbach's $\alpha$ using Nunnally's (1978) suggestions about the acceptability of the value (.70 is acceptable and .80 is good). However, Cronbach's $\alpha$ can be less reliable (Hair, Black, Babin, \& Anderson, 2014; Sijtsma, 2009) when the number of items is low. Therefore, we also calculated McDonald's (1970) omega coefficients of composite reliability with the following formula: $\omega=\left(\sum\left|\lambda_{\mathrm{i}}\right|\right)^{2} /\left(\left[\sum\left|\lambda_{\mathrm{i}}\right|\right]^{2}+\sum \delta_{\mathrm{ii}}\right)$, where $\lambda_{\mathrm{i}}$ represents the factor loadings and $\delta_{\text {ii }}$ represents the item-specific error variances. This index has the advantage of considering the strength of association between the items and the latent factors $\left(\lambda_{\mathrm{i}}\right)$, as well as item-specific measurement errors $\left(\delta_{\mathrm{ii}}\right)$ (e.g., Dunn, Baguley, \& Brunsden, 2014; Sijtsma, 2009).

\section{Ethics}

The present investigation (including Studies 1-3) was conducted in accordance with the Declaration of Helsinki and with the approval of the Institutional Review Board of the Eötvös Loránd University. All participants were informed about the goals of the study and provided informed consent. 


\section{RESULTS}

\section{Phase 1: Item selection and ESEM}

In the first part of the analysis, each of the initial 31 items was examined based on (a) their corrected item-total correlations, (b) normality in terms of skewness and kurtosis, and (c) content validity compared with the other items and series watching in general. Following these criteria, a total of 11 items were eliminated: seven as a result of low item-total correlation and four as a result of not adequate content. This first round of elimination resulted in 20 items (and five factors) that were retained for the subsequent analyses.

Next, ESEM was performed to further investigate the factor structure of the remaining items. The goal was to create a short measure; therefore, an additional five items were eliminated (due to having lower factor loadings compared with the other items, thus representing the overall constructs less) and three items per factor were preserved. The final model - with 5 factors and 15 items - showed good model fit $(\mathrm{CFI}=0.990$; $\mathrm{TLI}=0.975$; $\mathrm{RMSEA}=0.035$ [90\% CI 0.023-0.047]). Table 1 depicts the main results related to the standardized parameter estimates: factor loadings ranged from 0.40 to 0.93 . In addition, there were no cross-loadings higher than 0.16 .

Based on the results, the 15 items loaded strongly on the expected five factors, indicating an appropriate factor structure. The scale also appeared to be reliable in terms of internal consistency and model-based composite reliability ( $\alpha=0.69-0.85 ; \omega=0.67-0.84)$ with moderate correlations between the factors $(r=23-42)$. The final English version can be seen in Appendix 1A, whereas the final Hungarian version can be seen in Appendix 1B.

\section{Phase 2: CFA and model comparison}

Similar to the ESEM model, the first-order model indicated good fit $(\mathrm{CFI}=0.962 ; \mathrm{TLI}=0.950 ; \mathrm{RMSEA}=0.049[90 \%$ CI 0.042-0.057]). This solution confirmed that the scale has appropriate factor structure even with the more restrictive CFA approach. Factor loadings ranged from 0.49 to 0.91. The second-order model $(\mathrm{CFI}=0.955$; TLI $=0.944$; RMSEA $=0.052$ [90\% CI 0.045-0.059]) also indicated good fit, albeit slightly worse compared with the first-order model. Based on these results, all models were adequate and the scale had good factor structure.

The similarity of factor loadings was also evaluated based using PSI. The high value $(r=.95)$ indicated that the pattern of the factor loadings was highly similar across the two samples. Finally, the target coefficient was calculated to compare the first-order and the second-order models. The result was $0.873(T=223.253 / 255.607)$, indicating that the second-order series watching engagement latent factor explains $87.3 \%$ of the covariance between the five smaller latent engagement factors. Once again, internal consistency $(\alpha=0.71-0.84)$ and model-based composite reliability $(\omega=0.72-0.84)$ indices were adequate and the engagement factors were moderately associated with one another $(r=25-40)$. Based on these results, the first-order model was chosen as a default model.

\section{Labels of the factors}

A total of five factors were identified, three were considered as non-problematic and two were considered as problematic. The first non-problematic factor was Self-development, which can be defined as the realization of language learning through watching series. Many of the world's popular series

Table 1. Results of the exploratory structural equation modeling on the Series Watching Engagement Scale

\begin{tabular}{|c|c|c|c|c|c|}
\hline & \multicolumn{5}{|c|}{ Series Watching Engagement Scale factors } \\
\hline & $\begin{array}{c}\text { Self- } \\
\text { development }\end{array}$ & $\begin{array}{c}\text { Social } \\
\text { interaction }\end{array}$ & Identification & Persistence & Overuse \\
\hline 1. Series watching improved my language skills. & 0.62 & 0.16 & 0.01 & -0.07 & 0.10 \\
\hline 2. Language learning motives me to watch series. & 0.82 & 0.00 & 0.02 & 0.03 & 0.06 \\
\hline 3. Watching series motivates me to learn foreign languages. & 0.93 & -0.03 & -0.01 & 0.03 & -0.04 \\
\hline 4. I discuss what's going on in series with my acquaintances. & -0.00 & 0.93 & 0.01 & -0.02 & -0.02 \\
\hline 5. Series are often discussed topics at my workplace/school. & -0.00 & 0.66 & -0.01 & 0.08 & 0.04 \\
\hline 6. I talk about series with my family. & 0.07 & 0.40 & 0.08 & 0.00 & 0.01 \\
\hline $\begin{array}{l}\text { 7. During series watching I have recognized one of my life } \\
\text { situations. }\end{array}$ & 0.06 & 0.02 & 0.74 & -0.00 & -0.02 \\
\hline $\begin{array}{l}\text { 8. In the series I watch, characters are in life situations similar to } \\
\text { mine. }\end{array}$ & -0.00 & 0.02 & 0.83 & -0.02 & -0.01 \\
\hline $\begin{array}{l}\text { 9. While watching TV series, I sometimes feel like the same } \\
\text { situations happen in my life like in the characters'. }\end{array}$ & -0.03 & -0.02 & 0.81 & 0.05 & 0.04 \\
\hline 10. After a series has ended, I feel emptiness inside me. & 0.07 & 0.04 & 0.10 & 0.60 & 0.04 \\
\hline $\begin{array}{l}\text { 11. After a series has completely ended, I can hardly concentrate } \\
\text { on other things. }\end{array}$ & -0.02 & -0.02 & 0.03 & 0.76 & 0.06 \\
\hline 12. I can hardly take my mind off a completely ended series. & -0.01 & 0.01 & -0.04 & 0.93 & -0.04 \\
\hline 13. I watch too many episodes of series in a row. & 0.02 & 0.03 & -0.06 & 0.05 & 0.67 \\
\hline 14. I watch series even when I already should sleep. & 0.01 & 0.12 & 0.02 & 0.09 & 0.54 \\
\hline 15. I spend more time watching series than I would like to. & -0.01 & -0.12 & 0.04 & -0.05 & 0.70 \\
\hline
\end{tabular}

Note. All factor loadings are standardized. Loadings in bold belong to their main factors. Non-significant loadings $(p>.05)$ are italicized. 
are first available in the original language (e.g., English, Japanese, or Spanish), and later in the form of dubbed episodes. Therefore, many non-native speakers can use series watching as an enjoyable form of language learning. Based on the research on soap operas (e.g., Alexander, 1985; Babrow, 1987; Bondad-Brown, Rice, \& Pearce, 2012; Greenberg et al., 1982; Lemish, 1985; Livingstone, 1988; Perse, 1986; Rubin, 1977, 1985; Rubin \& Perse, 1987), series can be considered as an effective medium through which different types of information and knowledge can be spread, for instance, family foundation, AIDS prevention, information related to problem solving, or information about things that the individual has not done before.

The second non-problematic factor was Social interaction, which refers to the discussions about series. Those who are characterized with high levels of social interaction talk about series in various social contexts, such as family, workplace, or school. Several previous studies (e.g., Babrow, 1987; Bondad-Brown et al., 2012; Compesi, 1980; Greenberg et al., 1982; Greenberg \& Woods, 1999; Lemish, 1985; Livingstone, 1988; Perse \& Rubin, 1990; Rubin, 1977, 1985; Rubin \& Perse, 1987) have claimed that watching series can be a social activity as they can be viewed in smaller or larger groups. Therefore, it can be assumed that social interactions about series can be a good indicator of series watching engagement.

The third non-problematic factor was Identification, which refers to the viewers' identification with the stories or the characters of the series. It can be related to the perceived overlap between the viewer's life and the series' characters or events; therefore, it refers to the extent of commonality between the self and the series' content, which can have impact on one's identity formation. The extent of identification determines how much one feels like she/he is going through similar situations as the characters or the characters have similar lives like the given person. According to previous motivational studies, series can play an important role in the process of identity formation and they can be a potential basis of identification (e.g., Babrow, 1987; Carveth \& Alexander, 1985; Compesi, 1980; Greenberg \& Woods, 1999; Livingstone, 1988).

The fourth, problematic factor was Persistence, which can be considered as the main pillar of series watching engagement as it grasps the emotional bond between the self and the activity of series watching. Those individuals who are characterized by high levels of persistence feel emptiness after the series has ended and they can hardly concentrate on other matters. For them, it is hard to take their minds off it completely when the watched series is ended. Previously, a similar dimension was identified concerning soap operas - called as preference and attachment - which was one of the most important motivational forces to watch soap operas (Lemish, 1985). Simulataneously, similar, mainly unidimensional constructs have been hypothesized in motivational research (e.g., Demir \& Demir, 2013; Greenberg et al., 1982; Levy \& Windahl, 1985 as cited in Godlewski \& Perse, 2010; Perse, 1990; Whetmore \& Kielwasser, 1983).

Finally, the fifth problematic factor was Overuse, which can be defined as excessive series watching. It measures the excessive nature of series watching referring to the volume of the individual's series watching even if he/she does not have time. Furthermore, it grasps potential impacts of series watching on one's life. Excessive series watching could lead to life problems, such as sleeping or obligational problems. In previous motivational studies, the time consumption and the time-passing dimensions of soap operas were emphasized, which can be related to overuse (e.g., Babrow, 1987; Bondad-Brown et al., 2012; Compesi, 1980; Lemish, 1985; Greenberg et al., 1982; Livingstone, 1988; Perse, 1986, 1990; Perse \& Rubin, 1990; Rubin, 1977; Rubin \& Perse, 1987). However, overuse - as the negative side of series watching engagement - mainly focuses on the selfperceived negative consequences of watching series independently from the exact amount of time one spends with series watching. This factor cannot be interpreted as problematic series watching, because it only grasps two aspects of problematic series watching (i.e., problems and tolerance). Rather, it could be considered as an antechamber of problematic series watching.

\section{STUDY 2 - INVARIANCE TESTING OF THE SWES}

Is the factor structure of the SWES similar for men and women? Invariance testing was an adequate statistical approach to answer this question. Invariance testing assessed whether the same latent construct was measured in a similar manner in different groups (Meredith, 1993; Vandenberg, 2002; Vandenberg \& Lance, 2000). These groups can be distinguished by practically any characteristics, e.g., gender, language, or nationality. Invariance testing can be split into two types: measurement invariance, which referred to the testing of the relationships between the variables and the latent constructs, and structural invariance, which only evaluated the latent variables. A total of seven levels of invariance testing can be distinguished within these two categories: in the (a) configural model, all groups had the same factor structure and all parameters are freely estimated; in the (b) metric or weak model, factor loadings were constrained to be equal across the groups; in the (c) scalar or strong model, factor loadings were intercepts that are set to be equal; in the (d) residual or strict model, all error variances needed to be equal; in the (e) factor variance model, all factor variances were constrained to be equal across the groups; in the (f) factor covariance model, the covariances between the latent factors were set to be the same; finally, in the (g) factor mean model, the means of the latent factors were assumed to be the same (Milfont \& Fischer, 2010). Therefore, the following goal was to test gender invariance on the SWES.

\section{METHODS}

\section{Procedure}

Data collection occurred in August 2015 with the help of a Facebook page whose main profile is providing news and information about series. Participants were first informed about the aims and the content of the study. They were 
assured of their anonymity and the confidentiality of their answers. The sample for the invariance testing included 944 respondents (472 males and 472 females).

\section{Participants}

For males, the average age was $29.26(S D=10.37)$. Among males, 106 of the participants $(22.5 \%)$ lived in the capital, $80(16.9 \%)$ in county towns, $159(33.7 \%)$ in towns, and 77 $(16.3 \%)$ in villages (50 respondents did not mention their demographical data). Regarding their level of education, 37 (7.8\%) had primary school degree, $235(49.8 \%)$ had a highschool degree, and 150 (31.8\%) of them had a degree in higher education (bachelor, masters, or doctoral). Regarding their relationship status, 258 respondents $(54.6 \%)$ were single, $112(23.7 \%)$ were in a relationship, and $52(11 \%)$ were married.

For females, the average age was $28.46(S D=9.53)$. Among females, 163 of the participants (34.5\%) lived in the capital, $81(17.2 \%)$ in county towns, $150(31.8 \%)$ in towns, and $78(16.5 \%)$ in villages. Regarding their level of education, 51 (10.8\%) had primary school degree, 197 (41.7\%) had a high-school degree, and $224(47.5 \%)$ of them had a degree in higher education (bachelor, masters, or doctoral). Regarding their relationship status, 235 respondents (49.7\%) were single, $170(35.9 \%)$ were in a relationship, and $67(14.2 \%)$ were married.

\section{Measures}

The SWES was used (see the previous study).

\section{Statistical analysis}

To test model invariance between genders, several multigroup CFAs were carried out using Mplus 7.3. In the first step, the measurement model was freely estimated for both males and females. In the second step, the four levels (configural, metric, scalar, and residual) of measurement invariance were assessed. In the third step, the three levels (factor variance, factor covariance, and factor mean) of the structural invariance were tested.

The same goodness of fit indices and their cut-offs were applied that had been detailed in Study 1. In addition, relative change of fit indices between the increasingly constrained models was also observed: the difference between CFI values $(\Delta \mathrm{CFI})$, the difference between TLI values $(\triangle T L I)$, and the difference between the RMSEA values ( $\triangle$ RMSEA) were inspected (Chen, 2007; Cheung \& Rensvold, 2002) as the $\chi^{2}$ difference statistic is sensitive to large sample size (Morin, Marsh, \& Nagengast, 2013). The following criteria have been suggested for the acceptance of the more restricted, invariant models: $\Delta \mathrm{CFI} \leq 0.010$; $\Delta \mathrm{TFI} \leq 0.010$; and $\Delta \mathrm{RMSEA} \leq 0.015$ (Chen, 2007).

\section{Results}

Both measurement and structural invariance were examined regarding gender. Table 2 below demonstrates all the steps of the analysis and the results indicated that all levels of invariance have been established in the total sample. In step zero, the baseline models were estimated for both males and females, showing good fit. For measurement invariance testing, the parameters of the configural model (M1) were freely estimated and this configural model provided good fit for the data $(\mathrm{CFI}=0.977$; $\mathrm{TLI}=$ 0.969; RMSEA $=0.045$ [90\% CI 0.038-0.053]), indicating that the five-factor pattern is the same for both males and females. In the next, metric model (M2), factor loadings were constrained to be equal and compared with the previous model, this model did not result in significantly worse fit, indicating metric invariance across gender groups. In the case of the following scalar model (M3), the intercepts were constrained to be equal for men and women. There was no significant deterioration of fit compared with the previous model, resulting in scalar invariance across groups. In the next step (residual model, M4), the error variances of the items were assumed to be equal, and there was no significant deterioration with these constraints either.

Table 2. Tests of gender invariance on the Series Watching Engagement Scale (SWES)

\begin{tabular}{|c|c|c|c|c|c|c|c|c|c|}
\hline & $\chi^{2}$ & $d f$ & CFI & TLI & RMSEA $[90 \% \mathrm{CI}]$ & Models & $\Delta \mathrm{CFI}$ & $\Delta \mathrm{TLI}$ & $\Delta$ RMSEA \\
\hline \multicolumn{10}{|c|}{ Step 1: baseline models for both gender groups } \\
\hline Male $(N=472)$ & 155.329 & $80^{\circ}$ & 0.976 & 0.969 & $0.045[0.034-0.055]$ & & & & \\
\hline Female $(N=472)$ & 159.727 & 80 & 0.977 & 0.970 & $0.046[0.035-0.056]$ & & & & \\
\hline \multicolumn{10}{|c|}{ Step 2: Measurement invariance across gender groups } \\
\hline M1: Configural & 155.329 & 160 & 0.977 & 0.969 & $0.045[0.038-0.053]$ & & & & \\
\hline M2: Metric (weak) & 320.786 & 170 & 0.977 & 0.972 & $0.043[0.036-0.051]$ & M2 vs. M1 & 0.000 & 0.000 & -0.002 \\
\hline M3: Scalar (strong) & 375.513 & 180 & 0.971 & 0.966 & $0.048[0.041-0.055]$ & M3 vs. M2 & -0.006 & -0.006 & +0.006 \\
\hline M4: Residual (strict) & 471.856 & 195 & 0.966 & 0.964 & $0.049[0.043-0.056]$ & M4 vs. M3 & -0.005 & -0.002 & +0.001 \\
\hline \multicolumn{10}{|c|}{ Step 3: Structural invariance across gender groups } \\
\hline M5: Factor variance & 420.544 & 200 & 0.967 & 0.965 & $0.048[0.042-0.055]$ & M5 vs. M4 & +0.001 & +0.001 & -0.001 \\
\hline M6: Factor covariance & 438.534 & 210 & 0.966 & 0.966 & $0.048[0.042-0.054]$ & M6 vs. M5 & -0.001 & +0.001 & 0.000 \\
\hline M7: Factor mean & 456.377 & 215 & 0.964 & 0.965 & $0.049[0.043-0.055]$ & M7 vs. M6 & -0.002 & -0.001 & +0.001 \\
\hline
\end{tabular}

Note. $\chi^{2}$ : Chi-square; $d f$ : degrees of freedom; CFI: comparative fit index; TLI: Tucker-Lewis Index; RMSEA: root mean square error of approximation; CI: confidence interval; $\triangle$ CFI: change in CFI value compared with the previous model; $\Delta$ TLI: change in the TLI value compared with the previous model; $\triangle$ RMSEA: change in the RMSEA value compared with the previous model. 
For structural invariance testing, the variances of the latent factors were further constrained to be equal. For the factor variance model (M5), the variances of the five factors were set to be equal across men and women. As the fit changes have not reached the necessary cut-offs, the results confirm the factor variance invariance across the two groups. To establish factor covariance invariance (M6), the covariance between the latent factors have been fixed to be equal. The changes in the fit indices confirm this level on invariance. Finally, the factors' means were constrained to be equal (M7) and it also resulted in non-significant changes in model fit indices, suggesting that the factor means were equal for both men and women. The results provided strong support for the conclusion that the SWES demonstrated high levels of measurement and structural invariance across different gender groups.

\section{STUDY 3 - IDENTIFYING AT-RISK INDIVIDUALS WITH LPA OF THE SWES}

In this study, to identify possible subgroups of viewers, a person-centered statistical analytic approach was used, namely LPA (Collins \& Lanza, 2010). It is a mixturemodeling technique aiming to identify subgroups of people who gave similar responses to series watching variables. The subgroups were then compared based on problematic series watching scores, passion for series watching, time spent with series watching, and basic personality dimensions posited by the Big Five theory.

\section{METHODS}

\section{Procedure}

This study was also conducted using an online questionnaire system, filling out took approximately $13 \mathrm{~min}$. The data collection occurred in September-October 2015 with the help of websites and Facebook pages specialized in series. First, participants were informed about the goals and the content of the study. Their anonymity and the confidentiality of their answers were guaranteed. They received no financial compensation for the participation. They were asked to check a box if they agreed with the consent form and wished to participate.

\section{Participants}

A total of 1,581 respondents were recruited for this study. However, 61 were removed before data analysis due to being underaged or giving improper answers. A total of 1,520 individuals' data (1,098 female, $72.2 \%)$ were analyzed for the study, aged between 18 and $74\left(M_{\text {age }}=30.06\right.$, $\left.S D_{\text {age }}=11.17\right)$. About 408 of them $(26.8 \%)$ lived in the capital, $264(17.4 \%)$ in county towns, $576(37.9 \%)$ in towns, and $272(17.9 \%)$ in villages. Regarding their level of education, $142(9.4 \%)$ had primary school degree, 768 (50.5\%) had a high-school degree, and 610 (40.1\%) of them had a degree in higher education (bachelor, masters, or doctoral).

\section{Measures}

Series Watching Engagement Scale (SWES). The same measure was administered as in previous studies. In this study, the Cronbach's $\alpha$ values were adequate as well $\left(\alpha_{\text {self-development }}=.80, \quad \alpha_{\text {identification }}=.86, \quad \alpha_{\text {overuse }}=75\right.$, $\alpha_{\text {persistence }}=.89$, and $\alpha_{\text {socialinteraction }}=.73$ ).

Problematic Series Watching Scale (PSWS). This scale (Orosz, Bőthe, \& Tóth-Király, 2016) assessed problematic series watching based on the theoretical framework of Griffiths (2005). It measured problematic series watching based on the six core elements of addictions: (a) tolerance, (b) mood modification, (c) withdrawal, (d) relapse, (e) salience, and (f) conflict $(\alpha=0.78)$. Participants were asked to answer using a 5-point scale $(1=$ never and 5 = always).

Series Watching Passion Scale. The Passion Scale (TóthKirály, Bőthe, Rigó, \& Orosz, 2017; Vallerand, 2015) measured the individual's passion toward an activity in two dimensions: harmonious (six items, e.g., "Series watching is well integrated in my life.," $\alpha=0.75$ ) and obsessive passion (six items, e.g., "Series watching is the only thing that really turns me on.," $\alpha=0.88$ ). In the case of this study, the Passion Scale focused on "series watching." Respondents had to indicate their level of agreement on a 7-point scale (ranging from $1=$ not agree at all to $7=$ very strongly agree).

Time spent with series watching. Respondents were asked to estimate the amount of time (expressed in minutes) they spent with watching series on an average weekday and on an average weekend. To have a single indicator of average series watching time for an average day, the reported values were weighted by the following formula: (weekday watching time $\times 5+$ weekend watching time $\times 2) / 7$. A threshold of $840 \mathrm{~min}(14 \mathrm{hr})$ was used as an upper limit to minimize bias. Greater values were recoded as missing. Respondents reporting 0 min (eight respondents) and above $14 \mathrm{hr} /$ day (two respondents) were excluded. With this calculation, on an average day, respondents watched series for $140.66 \mathrm{~min}$ on average $(S D=115.71)$.

Big Five Inventory (BFI). The Big Five Inventory (John \& Srivastava, 1999) was a 45-item scale measuring the personality of the respondent by five dimensions: extraversion $(\alpha=0.77)$, agreeableness $(\alpha=0.63)$, conscientiousness $(\alpha=0.67)$, neuroticism $(\alpha=0.78)$, and openness $(\alpha=0.86)$. A shorter, valid, Hungarian version was created by Farkas and Orosz (2013) that contained 15 items. Respondents used a 5-point scale to indicate their level of agreement (ranging from $1=$ strongly disagree to $5=$ strongly agree).

\section{Statistical analysis}

LPA was performed on the five series watching engagement dimensions. Mplus 7.3 (Muthén \& Muthén, 1998-2015) was used. The analysis was performed with two-four classes on the full sample. To determine the number of latent classes, several indices were used: the Akaike Information Criterion (AIC), the Bayesian Information Criterion (BIC), and the Sample-Size Adjusted Bayesian Information Criterion (SSABIC). In the case of these three indices, lower values indicate more parsimonious models. Moreover, 
entropy was also calculated that shows the accuracy of the classification process. Higher values indicate higher accuracy with 0.40 being low, 0.60 being medium, and 0.80 being high entropy (Clark \& Muthén, 2009). The Lo-Mendell-Rubin Adjusted Likelihood Ratio Test (L-M-R Test) was also used. This test compares the estimated model (e.g., three classes) with a model having one less class (e.g., two classes). A statistically significant $p$ value $(p<.05)$ suggests that the model with more classes fits the data better. Alternatively, if the $p$ value was not significant $(p>.05)$, then the model with more classes should be rejected, and the model with one less class should be accepted (Muthén \& Muthén, 1998-2015). After establishing the number of latent classes, analysis of variance with Bonferroni post-hoc test was carried out to test the validity of the classes by comparing them along several variables (mean scores of problematic series watching, harmonious and obsessive passion time spent with series watching, and the five personality dimensions).

\section{RESULTS}

Correlations between the variables can be seen in Table 3. In short, all series watching engagement dimensions positively and significantly correlated with the proximal variables, such as harmonious and obsessive passion and problematic series watching (ranging from 0.26 to 0.71 ). Of major importance, the hypothesized problematic aspects of series watching engagement (persistence and overuse) more strongly correlated with obsessive passion and problematic series watching. On the other hand, the non-problematic engagement aspects (self-development, social interaction, and identification) were more strongly associated with harmonious passion. Interestingly, Persistence also had a similarly high correlation with harmonious passion. As for time spent with series watching, the correlation between the aggregated score of SWES and viewing time was significant $[r(1,378)=.25, p<.001]$. Regarding the specific dimensions, viewing time was more strongly related to the problematic engagement aspects. In terms of personality, only weak associations were found. Overall, these findings lend further support to the overall convergent validity of the SWES.

We then addressed the question of potential subgroups of viewers. LPA was performed on the series watching engagement factors (Table 4). The AIC, BIC, and SSABIC values continuously decreased as the number of latent classes was increased. Regarding entropy, the two- and three-class solutions could be considered acceptable, whereas the four-class solution demonstrated medium levels of accuracy. The non-significant $p$ value of the L-M-R Test suggested that the four-class solution should be rejected in favor of the three-class solution. Based on the above-listed criteria, the three-class solution was selected.

The three latent classes with their respective relationship patterns can be seen on Figure 1. The first class (low engagement viewers) represented viewers scoring low on all dimensions of series watching engagement (383 individuals, 25.2\%). The second class (medium engagement viewers) represented viewers with medium levels of engagement (635 individuals, 41.8\%). The third class (high 
Series watching engagement

Table 4. Fit indices for the latent profile analysis on the Series Watching Engagement Scale

\begin{tabular}{lcccccr}
\hline Classes & AIC & BIC & SSABIC & Entropy & L-M-R Test & \multicolumn{1}{c}{$p$} \\
\hline 2 & 44,155 & 44,241 & 44,190 & 0.740 & 1,254 & $<.001$ \\
$\mathbf{3}$ & $\mathbf{4 3 , 8 9 5}$ & $\mathbf{4 4 , 0 1 3}$ & $\mathbf{4 3 , 9 4 3}$ & $\mathbf{0 . 7 2 4}$ & $\mathbf{2 6 5}$ & $<.001$ \\
4 & 43,798 & 43,948 & 43,859 & 0.672 & 106 & .099 \\
\hline
\end{tabular}

Note. Bold values indicate that the three-class solution was selected as the final model. Classes: number of latent classes; AIC: Akaike Information Criterion; BIC: Bayesian Information Criterion; SSABIC: Sample-Size Adjusted Bayesian Information Criterion; L-M-R test: The Lo-Mendell-Rubin Adjusted Likelihood Ratio Test; $p=p$ value associated with the L-M-R Test.

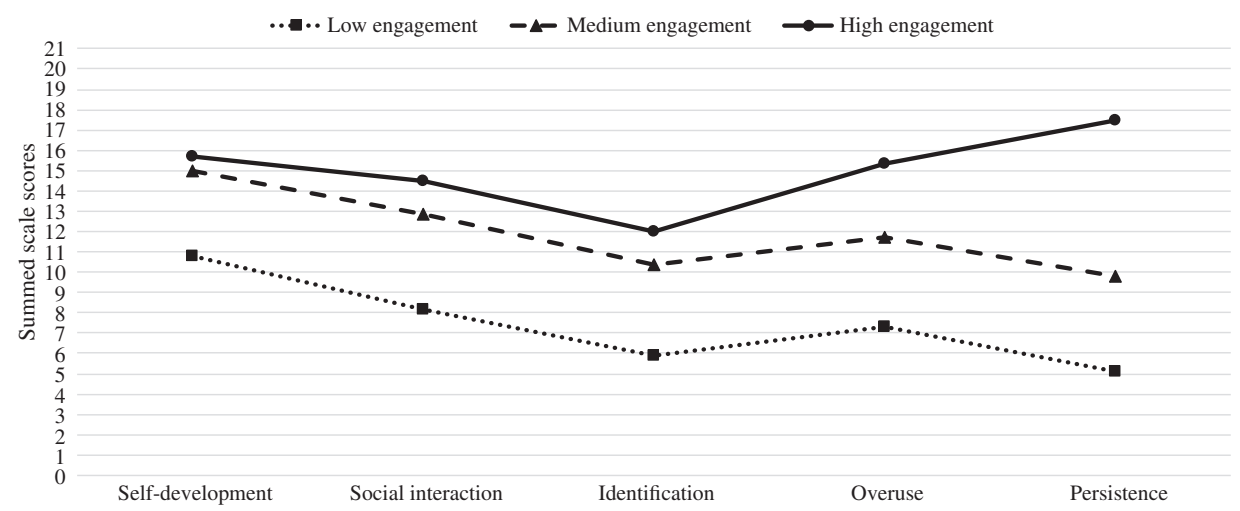

Figure 1. Latent classes based on the dimensions of the Series Watching Engagement Scale

engagement viewers) represented viewers with high levels of engagement (502 individuals, 33.0\%). The relationship patterns of the factor were highly similar and mirrored each other in the case of class 1 and 2, only on different levels of engagement. In the case of class 3 , this pattern slightly deviated from the other two as Persistence was on an increased level.

The three latent classes and their characteristics can be seen in Table 5. Viewers belonging to the high engagement group had higher scores on problematic series watching, harmonious and obsessive passion, spent more time with series watching had lower scores on conscientiousness and had higher scores on neuroticism.

\section{GENERAL DISCUSSION}

In the new era of TV series watching, viewers have much more autonomy in freely deciding what, when, where, and how they want to watch. The present results - with almost $2 \frac{1}{2} \mathrm{hr}$ of viewing time on an average day - also support that they spend a significant amount of their time with this activity (Fisher \& Robinson, 2011; Purcell, 2010). For this reason, it might be important to revisit how people are connected to this activity and to reexamine the role it plays in their life. As problematic behaviors could easily develop in the case of screen-based behaviors (for instance, online gaming or Internet use), it is

Table 5. Comparison of the three latent classes in problematic series watching, time spent with series watching and Big Five dimensions

\begin{tabular}{|c|c|c|c|c|c|c|}
\hline & \multirow[b]{2}{*}{ Range } & \multirow{2}{*}{$\begin{array}{c}\text { (a) Low- } \\
\text { engagement } \\
\text { viewers }(N=383)\end{array}$} & \multirow{2}{*}{$\begin{array}{l}\text { (b) Medium- } \\
\text { engagement viewers } \\
(N=635)\end{array}$} & \multirow{2}{*}{$\begin{array}{c}\text { (c) High- } \\
\text { engagement } \\
\text { viewers }(N=502)\end{array}$} & \multicolumn{2}{|c|}{ ANOVA } \\
\hline & & & & & $F$ & $p$ \\
\hline Problematic series watching & $6-30$ & $9.39(3.25)^{\mathrm{b}, \mathrm{c}}$ & $13.25(4.10)^{\mathrm{a}, \mathrm{c}}$ & $16.46(4.90)^{\mathrm{a}, \mathrm{b}}$ & 308.94 & $<.001$ \\
\hline Time spent with watching (min/day) & - & $116.56(84.30)^{\mathrm{c}}$ & $130.88(82.65)^{\mathrm{c}}$ & $169.61(109.97)^{\mathrm{a}, \mathrm{b}}$ & 36.46 & $<.001$ \\
\hline Harmonious passion & $6-42$ & $22.94(6.85)^{\mathrm{b}, \mathrm{c}}$ & $28.57(5.76)^{\mathrm{a}, \mathrm{c}}$ & $31.47(6.73)^{\mathrm{a}, \mathrm{b}}$ & 230.16 & $<.001$ \\
\hline Obsessive passion & $6-42$ & $9.36(4.09)^{\mathrm{b}, \mathrm{c}}$ & $15.11(6.21)^{\mathrm{a}, \mathrm{c}}$ & $22.30(8.14)^{\mathrm{a}, \mathrm{b}}$ & 442.68 & $<.001$ \\
\hline Extraversion & $3-15$ & $10.23(3.03)$ & $9.97(3.05)$ & $9.94(3.19)$ & 1.15 & .316 \\
\hline Agreeableness & $3-15$ & $10.99(2.16)$ & $11.06(2.26)$ & $11.08(2.41)$ & 0.19 & .826 \\
\hline Conscientiousness & $3-15$ & $10.42(2.57)^{\mathrm{b}, \mathrm{c}}$ & $9.28(2.61)^{\mathrm{a}, \mathrm{c}}$ & $8.68(2.54)^{\mathrm{a}, \mathrm{b}}$ & 50.22 & $<.001$ \\
\hline Neuroticism & $3-15$ & $8.03(2.94)^{\mathrm{b}, \mathrm{c}}$ & $8.68(2.77)^{\mathrm{a}, \mathrm{c}}$ & $9.60(2.94)^{\mathrm{a}, \mathrm{b}}$ & 33.60 & $<.001$ \\
\hline Openness & $3-15$ & $10.52(3.24)$ & $10.94(3.12)$ & $10.97(3.07)$ & 2.71 & .065 \\
\hline
\end{tabular}

Note. Superscript letters indicate mean differences between the classes. Numbers in parentheses are standard deviations. 
important and necessary to filter out those individuals who might be at-risk of developing problematic series watching, which can be highly associated with negative consequences, such as anxiety (e.g., Mentzoni et al., 2011), depression (Bélanger et al., 2011), sleeping problems (Do et al., 2013), or psychiatric conditions (Andreassen et al., 2016). For this purpose, the aim of the present multistudy investigation was to (a) create a questionnaire, which is able to measure series watching engagement with its most important problematic and nonproblematic aspects; and to (b) identify at-risk, highly engaged individuals. We will now discuss our findings as well as potential implications and limitations.

\section{Series watching engagement: Conceptualized and operationalized}

In the 1980-1990s, scientific research primarily focused on the different motivational forces that drove individuals to series (e.g., Alexander, 1985; Greenberg et al., 1982; Perse, 1986; Rubin, 1985) with little to no emphasis being put on engagement. At the same time, multiple interpretations of engagement were used such as affinity (Greenberg, 1974 as cited in Perse, 1986; Rubin, 1977, 1979) and different involvement interpretations (Levy \& Windahl, 1985 as cited in Godlewski \& Perse, 2010; Perse, 1990; Whetmore \& Kielwasser, 1983). In the present research, by applying the concept of engagement from the field of gaming (Brunborg et al., 2013, 2014; Charlton, 2002; Charlton \& Danforth, 2007, 2010; Ferguson et al., 2011), all of these different, alternative notions were incorporated and represented under the umbrella of a unifying engagement concept. This unifying engagement concept - incorporating the most recent online behavior results was hypothesized to have both non-problematic and problematic aspects. These five aspects were persistence, identification, overuse, social interaction, and self-development.

After uncovering and operationalizing these possible components, thorough and exhaustive statistical analyses were performed - including ESEM (Asparouhov \& Muthén, 2009; Marsh et al., 2014) and CFA - to examine this newly developed instrument. Both analyses suggested that an adequate measure was created. As suggested by these analyses, the five-factor first-order model was the best fitting solution. Further reliability and validity indices were also adequate in terms of Cronbach's $\alpha$ values and model-based composite reliability indices. High levels of invariance (invariance of factor loadings, intercepts, error variances, factor variances, factor covariances, and factor means) were demonstrated across gender groups, supporting the generalizability of the construct of series watching engagement.

Viewing time as a behavioral marker of the series watching activity was related to series watching engagement. However, the specific factors correlated with time to a different extent. The highest correlation was measured between time and overuse, whereas the lowest (non-significant) was assessed between time and social interaction. Considering all dimensions of SWES, problematic aspects of series watching were more strongly related to viewing time than non-problematic ones. However, one should be careful not to overpathologize this behavior (Billieux et al., 2015; Maráz, Király, \& Demetrovics, 2015).
Regarding the associations between the engagement dimensions and the proximal variables, all engagement facets showed moderate to high correlation with problematic series watching, giving further support to the notion that engagement can be considered as a potential precursor of problematic use (e.g., Brunborg et al., 2013; Charlton \& Danforth, 2007). More specifically, supposedly problematic engagement aspects (persistence and overuse) were more strongly related to obsessive passion and problematic series watching, whereas non-problematic aspects (self-development, social interaction, and identification) were more strongly related to harmonious passion. Persistence was moderately related to harmonious passion as well. One possible explanation might be that persistence describes the emotional bond between the individual and the series, and this bond indicates that the activity of series watching became an important part of the individual's life. Similarly, in the case of harmonious and obsessive passion, the given activity is an integral part of the individual (Vallerand, 2015). Persistence grasps the basic requirement of passion irrespective of its harmonious or obsessive nature. These observations are also supported by the fact that engagement and passion indeed have a small degree of overlap; however, the former is only a state construct and encompass only two core elements of passion (i.e., engagement also refers to a specific activity and regulates persistent and effortful behaviors toward the activity; see Curran, Hill, Appleton, Vallerand, \& Standage, 2015)

\section{Identifying potential at-risk groups}

To establish subgroups of viewers and to compare their characteristics, LPA was conducted. The results revealed a three-class solution based on the five series watching engagement dimensions: low-, medium-, and high-engagement viewers. When comparing the patterns of the three classes (Figure 1), it can be seen that low- and medium-engagement viewers had almost the same patters, only on different levels of engagement. In contrast, highly engaged, at-risk viewers one third of the current sample - can be distinguished from these two groups on the basis of the elevated levels of persistence.

As for group differences, the highly engaged group had higher scores on problematic series watching and they spent more time with series watching on a daily basis. Although highly engaged viewers had the highest watching times, it has to be noted that - just like in the case of other online behaviors (e.g., Baggio et al., 2016; Brand et al., 2011; Caplan \& High, 2006; Demetrovics \& Király, 2016; Griffiths, 2010; Peters \& Malesky, 2008; Twohig, Crosby, \& Cox, 2009) - time spent with the activity alone might not be an adequate and satisfactory indicator. The present research also supports this notion. As problematic use could grasp more above and beyond time spent with the activity, we suppose that - similarly to passion (Orosz, Vallerand, Bőthe, Tóth-Király, \& Paskuj, 2016) - the concept of engagement might also be able to reveal deeper layers of involvement that can help in the understanding of problematic versus non-problematic behaviors. As previously mentioned, it is important to be careful with the overpathologization of online behaviors on the basis of the 
time one spends with the given activity (Billieux et al., 2015). Interestingly, the highly engaged group had higher scores on harmonious and obsessive passion as well, although the group differences were more pronounced in the case of obsessive passion.

Regarding the basic personality dimensions, differences were observed in the case of conscientiousness and neuroticism: highly engaged were less conscientious and more neurotic. Supposedly, highly conscientious individuals preferred spending time with duties and important tasks rather than online activities (e.g., Graham \& Gosling, 2013; Landers \& Lounsbury, 2006; Peters \& Malesky, 2008; Ryan \& Xenos, 2011), whereas highly neurotic individuals pursued screenrelated activities more frequently and intensively (e.g., Correa, Hinsley, \& De Zuniga, 2010; Dong, Wang, Yang, \& Zhou, 2013; Hamburger \& Ben-Artzi, 2000); thus it was reasonable that they were more involved in series watching. In their case, another important question would be the identification of viewers' motivations that can fill the gap between personality traits and the different types of engagement that can lead to problematic versus non-problematic behaviors. In sum, these results concur with previous studies examining the relationship of personality and other screenrelated behaviors (e.g., Andreassen et al., 2013; Orosz, TóthKirály, et al., 2016).

\section{Limitations and future directions}

The present work is not without limitations. Although the utilized samples were diverse, the present results could not be generalized to the population. For this purpose, a more comprehensive, representative sample should be used. Replications in other cultures should also be performed as different cultural and socioeconomic characteristics could also influence one's series watching activity. All respondents were adults in all samples; however, it would be important to explore series watching among younger audiences (such as teens) or elderly individuals as well. As with other questionnaire-based studies, self-reporting can lead to possible biases (e.g., recall bias or social desirability bias), which have to be considered. These tools should be complemented with objective ones that could directly measure not only self-reported series watching behavior while respecting the privacy of the individuals. Causality cannot be inferred based on these correlation-based analyses. Within the framework of the current research, only cross-sectional studies were employed, which did not allow the investigation of different life events that could influence series watching. A longitudinal design would be fruitful in examining how potential life events (e.g., breakup or unemployment) could affect the individual in pursuing this activity. Moreover, different aspects of series watching could have different life outcomes (e.g., time spent with friends or the neglect of obligations and other hobbies). Further emphasis should be put on the social aspects of series watching (i.e., watching it with others) and the basic psychological needs (Ryan \& Deci, 2017; Tóth-Király, Morin, Bőthe, Orosz, \& Rigó, 2017) this activity can fulfill. Alternatively, an experimental design could be employed to determine the causal role of series watching engagement on the activity itself.
A fundamentally important task of future studies would be the clear conceptualization of the activity of series watching. As of the time of this research, series watching can still be miscalculated and underrepresented in the population by not considering differences such as platforms (i.e., Netflix vs. others), geographical restrictions (i.e., USA vs. Europe), means of access (legal vs. illegal), or mediums of consumption (i.e., smartphone vs. television box). Future research should strive to measure time spent with series watching more precisely as it is an important indicator. The differentiation of series watching engagement, series watching motivations, and problematic series watching should be investigated with novel statistical procedures. Finally, health-related variables (such as well-being, perceived stress, or anxiety) should be examined in relation to both series watching engagement and problematic use to further differentiate these two concepts.

\section{CONCLUSIONS}

As viewers have more and more autonomy about what, when, and where they watch series, it is becoming increasingly important to identify potential at-risk viewers before the development of problematic use. For this purpose, the SWES might be an adequate tool, which demonstrated good psychometric properties and it can assess the most important problematic and non-problematic dimensions of series watching engagement, namely persistence, identification, overuse, social interaction, and self-development. Despite series watching engagement referring to the normal, nonproblematic series watching activity, individuals with high levels of engagement can be considered as an at-risk group that could easily develop problematic use. Quantifying series watching engagement in this new era can help in understanding the increasing allocation of valuable leisure time on this screen-based activity.

Funding sources: IT-K was supported by the ÚNKP-17-3 New National Excellence Program awarded by the Hungarian Ministry of Human Capacities. GO was supported by the Hungarian Research Fund (NKFI PD 116686, FK 124225).

Authors' contribution: All authors contributed to the study design and concept, data analysis, and interpretation of the data. IT-K wrote the first draft of the manuscript as an MA thesis with input from GO as a supervisor. All authors contributed to and have approved the final version of the manuscript.

Conflict of interest: The authors declare no conflict of interest.

Acknowledgements: The authors are very grateful for the substantial contribution of the students of Eötvös Loránd University in the item construction. They would also like to thank for Dr. Anikó Maráz for her constructive and helpful suggestions and advices on the earlier version of the manuscript. 


\section{REFERENCES}

Alexa.com. (2016). The top 500 sites on the web. Retrieved March 20, 2016, from http://www.alexa.com/topsites

Alexander, A. (1985). Adolescents' soap opera viewing and relational perceptions. Journal of Broadcasting \& Electronic Media, 29(3), 295-308. doi:10.1080/08838158509386586

Andreassen, C. S. (2015). Online social network site addiction: A comprehensive review. Current Addiction Reports, 2(2), 175-184. doi:10.1007/s40429-015-0056-9

Andreassen, C. S., Billieux, J., Griffiths, M. D., Kuss, D. J., Demetrovics, Z., Mazzoni, E., \& Pallesen, S. (2016). The relationship between addictive use of social media and video games and symptoms of psychiatric disorders: A large-scale cross-sectional study. Psychology of Addictive Behaviors, 30(2), 252-262. doi:10.1037/adb0000160

Andreassen, C. S., Griffiths, M. D., Gjertsen, S. R., Krossbakken, E., Kvam, S., \& Pallesen, S. (2013). The relationships between behavioral addictions and the five-factor model of personality. Journal of Behavioral Addictions, 2(2), 90-99. doi:10.1556/ JBA.2.2013.003

Ang, R. P., Chong, W. H., Chye, S., \& Huan, V. S. (2012). Loneliness and generalized problematic Internet use: Parents' perceived knowledge of adolescents' online activities as a moderator. Computers in Human Behavior, 28(4), 13421347. doi:10.1016/j.chb.2012.02.019

Asparouhov, T., \& Muthén, B. (2009). Exploratory structural equation modeling. Structural Equation Modeling: A Multidisciplinary Journal, 16(3), 397-438. doi:10.1080/107055109 03008204

Babrow, A. S. (1987). Student motives for watching soap operas. Journal of Broadcasting \& Electronic Media, 31(3), 309-321. doi:10.1080/08838158709386666

Baggio, S., Dupuis, M., Studer, J., Spilka, S., Daeppen, J. B., Simon, O., Berchtold, A., \& Gmel, G. (2016). Reframing video gaming and Internet use addiction: Empirical cross-national comparison of heavy use over time and addiction scales among young users. Addiction, 111(3), 513-522. doi:10.1111/add. 13192

Bélanger, R. E., Akre, C., Berchtold, A., \& Michaud, P. A. (2011). A U-shaped association between intensity of Internet use and adolescent health. Pediatrics, 127(2), e330-e335. doi:10.1542/ peds.2010-1235

Bernardi, S., \& Pallanti, S. (2009). Internet addiction: A descriptive clinical study focusing on comorbidities and dissociative symptoms. Comprehensive Psychiatry, 50(6), 510-516. doi:10.1016/ j.comppsych.2008.11.011

Billieux, J., Schimmenti, A., Khazaal, Y., Maurage, P., \& Heeren, A. (2015). Are we overpathologizing everyday life? A tenable blueprint for behavioral addiction research. Journal of Behavioral Addictions, 4(3), 119-123. doi:10.1556/2006.4. 2015.009

Bondad-Brown, B. A., Rice, R. E., \& Pearce, K. E. (2012). Influences on TV viewing and online user-shared video use: Demographics, generations, contextual age, media use, motivations, and audience activity. Journal of Broadcasting \& Electronic Media, 56(4), 471-493. doi:10.1080/08838151. 2012.732139

Brand, M., Laier, C., Pawlikowski, M., Schächtle, U., Schöler, T., \& Altstötter-Gleich, C. (2011). Watching pornographic pictures on the Internet: Role of sexual arousal ratings and psychological-psychiatric symptoms for using Internet sex sites excessively. Cyberpsychology, Behavior, and Social Networking, 14(6), 371-377. doi:10.1089/cyber.2010.0222

Brunborg, G. S., Mentzoni, R. A., \& Frøyland, L. R. (2014). Is video gaming, or video game addiction, associated with depression, academic achievement, heavy episodic drinking, or conduct problems? Journal of Behavioral Addictions, 3(1), 27-32. doi:10.1556/JBA.3.2014.002

Brunborg, G. S., Mentzoni, R. A., Melkevik, O. R., Torsheim, T., Samdal, O., Hetland, J., Andreassen, C. S., \& Palleson, S. (2013). Gaming addiction, gaming engagement, and psychological health complaints among Norwegian adolescents. Media Psychology, 16(1), 115-128. doi:10.1080/15213269.2012.756374

Caplan, S. E., \& High, A. C. (2006). Beyond excessive use: The interaction between cognitive and behavioral symptoms of problematic Internet use. Communication Research Reports, 23(4), 265-271. doi:10.1080/08824090600962516

Carveth, R., \& Alexander, A. (1985). Soap opera viewing motivations and the cultivation process. Journal of Broadcasting \& Electronic Media, 29(3), 259-273. doi:10.1080/088381585 09386584

Charlton, J. P. (2002). A factor-analytic investigation of computer 'addiction' and engagement. British Journal of Psychology, 93(3), 329-344. doi:10.1348/000712602760146242

Charlton, J. P., \& Danforth, I. D. (2007). Distinguishing addiction and high engagement in the context of online game playing. Computers in Human Behavior, 23(3), 1531-1548. doi:10. 1016/j.chb.2005.07.002

Charlton, J. P., \& Danforth, I. D. (2010). Validating the distinction between computer addiction and engagement: Online game playing and personality. Behaviour \& Information Technology, 29(6), 601-613. doi:10.1080/01449290903401978

Chen, F. F. (2007). Sensitivity of goodness of fit indexes to lack of measurement invariance. Structural Equation Modeling, 14(3), 464-504. doi:10.1080/10705510701301834

Cheung, G. W., \& Rensvold, R. B. (2002). Evaluating goodnessof-fit indexes for testing measurement invariance. Structural Equation Modeling, 9(2), 233-255. doi:10.1207/S153280 07SEM0902_5

Clark, S. L., \& Muthén, B. (2009). Relating latent class analysis results to variables not included in the analysis. Submitted for publication. Retrieved March 4, 2016, from http://statmodel2. com/download/relatinglca.pdf

Collins, L. M., \& Lanza, S. T. (2010). Latent class and latent transition analysis. With applications in the social, behavioral, and health sciences. Hoboken, NJ: Wiley.

Compesi, R. J. (1980). Gratifications of daytime TV serial viewers. Journalism Quarterly, 57(1), 155-158. doi:10.1177/1077699 08005700126

Cord Cutting. (n.d.). Oxford dictionaries. Retrieved March 20, 2016, from http://www.oxforddictionaries.com/definition/ english/cord-cutting

Correa, T., Hinsley, A. W., \& De Zuniga, H. G. (2010). Who interacts on the Web?: The intersection of users' personality and social media use. Computers in Human Behavior, 26(2), 247-253. doi:10.1016/j.chb.2009.09.003

Curran, T., Hill, A. P., Appleton, P. R., Vallerand, R. J., \& Standage, M. (2015). The psychology of passion: A metaanalytical review of a decade of research on intrapersonal 
outcomes. Motivation and Emotion, 39(5), 631-655. doi:10. 1007/s11031-015-9503-0

Demetrovics, Z., \& Király, O. (2016). Commentary on Baggio et al. (2016): Internet/gaming addiction is more than heavy use over time. Addiction, 111(3), 523-524. doi:10.1111/add.13244

Demir, M. Ö., \& Demir, Z. G. (2013). The uses and gratifications approach of TV series viewers in Turkey. Akademik Bakış Journal, 39, 1-20.

Do, Y. K., Shin, E., Bautista, M. A., \& Foo, K. (2013). The associations between self-reported sleep duration and adolescent health outcomes: What is the role of time spent on Internet use? Sleep Medicine, 14(2), 195-200. doi:10.1016/j.sleep.2012.09.004

Dong, G., Wang, J., Yang, X., \& Zhou, H. (2013). Risk personality traits of Internet addiction: A longitudinal study of Internetaddicted Chinese university students. Asia-Pacific Psychiatry, 5(4), 316-321. doi:10.1111/j.1758-5872.2012.00185.x

Dunn, T., Baguley, T., \& Brunsden, V. (2014). From alpha to omega: A practical solution to the pervasive problem of internal consistency. British Journal of Psychology, 105(3), 399-412. doi:10.1111/bjop.12046

Ellison, N. B., Steinfield, C., \& Lampe, C. (2007). The benefits of Facebook "Friends:" Social capital and college students' use of online social network sites. Journal of Computer-Mediated Communication, 12(4), 1143-1168. doi:10.1111/j.1083-6101. 2007.00367.x

Fahlman, S. A., Mercer-Lynn, K. B., Flora, D. B., \& Eastwood, J. D. (2013). Development and validation of the multidimensional state boredom scale. Assessment, 20(1), 68-85. doi:10. $1177 / 1073191111421303$

Farkas, D., \& Orosz, G. (2013). The link between ego-resiliency and changes in Big Five traits after decision making: The case of Extraversion. Personality and Individual Differences, 55(4), 440-445. doi:10.1016/j.paid.2013.04.003

Ferguson, C. J., Coulson, M., \& Barnett, J. (2011). A meta-analysis of pathological gaming prevalence and comorbidity with mental health, academic and social problems. Journal of Psychiatric Research, 45(12), 1573-1578. doi:10.1016/j.jpsychires. 2011.09.005

Fisher, K., \& Robinson, J. (2011). Daily life in 23 countries. Social Indicators Research, 101(2), 295-304. doi:10.1007/s11205010-9650-3

Godlewski, L. R., \& Perse, E. M. (2010). Audience activity and reality television: Identification, online activity, and satisfaction. Communication Quarterly, 58(2), 148-169. doi:10.1080/ 01463371003773358

Graham, L. T., \& Gosling, S. D. (2013). Personality profiles associated with different motivations for playing World of Warcraft. Cyberpsychology, Behavior, and Social Networking, 16(3), 189-193. doi:10.1089/cyber.2012.0090.

Greenberg, B. S. (1974). Gratifications of television viewing and their correlates for British children. In J. G. Blumler \& E. Katz (Eds.), The uses of mass communications: Current perspectives on gratifications research (pp. 71-92). Beverly Hills, CA: Sage. (as cited in Perse, 1986)

Greenberg, B. S., Neuendorf, K., Rothfuss, N. B., \& Henderson, L. (1982). The soaps: What's on and who cares? Journal of Broadcasting \& Electronic Media, 26(2), 519-535. doi:10. 1080/08838158209364022

Greenberg, B. S., \& Woods, M. G. (1999). The soaps: Their sex, gratifications, and outcomes. Journal of Sex Research, 36(3), 250-257. doi:10.1080/00224499909551995
Griffiths, M. (2005). A 'components' model of addiction within a biopsychosocial framework. Journal of Substance Use, 10(4), 191-197. doi:10.1080/14659890500114359

Griffiths, M. D. (2010). The role of context in online gaming excess and addiction: Some case study evidence. International Journal of Mental Health and Addiction, 8(1), 119-125. doi:10.1007/s11469-009-9229-x

Hair, J. F. Jr., Black, W. C., Babin, B. J., \& Anderson, R. E. (2014). Multivariate data analysis (7th Ed.). Essex, UK: Pearson.

Hamburger, Y. A., \& Ben-Artzi, E. (2000). The relationship between extraversion and neuroticism and the different uses of the Internet. Computers in Human Behavior, 16(4), 441449. doi:10.1016/S0747-5632(00)00017-0

Haynes, S. N., Richard, D., \& Kubany, E. S. (1995). Content validity in psychological assessment: A functional approach to concepts and methods. Psychological Assessment, 7(3), 238247. doi:10.1037/1040-3590.7.3.238

Heisler, Y. (2015). Cable providers still have no answer for Netflix as cord-cutting accelerates. BGR. Retrieved March 20, 2016, from http://bgr.com/2015/12/11/cable-tv-decline-cord-cutting/

Hu, L., \& Bentler, P. M. (1999). Cutoff criteria for fit indexes in covariance structure analysis: Conventional criteria versus new alternatives. Structural Equation Modeling, 6(1), 1-55. doi:10. 1080/10705519909540118

John, O. P., \& Srivastava, S. (1999). The Big Five trait taxonomy: History, measurement, and theoretical perspectives. In L. A. Pervin \& O. P. John (Eds.), Handbook of personality: Theory and research (2nd ed., pp. 102-138). New York, NY: Guilford Press.

Kelley, K. J., \& Gruber, E. M. (2010). Psychometric properties of the Problematic Internet Use Questionnaire. Computers in Human Behavior, 26(6), 1838-1845. doi:10.1016/j.chb.2010.07.018

Kelley, K. J., \& Gruber, E. M. (2013). Problematic Internet use and physical health. Journal of Behavioral Addictions, 2(2), 108112. doi:10.1556/JBA.1.2012.016

Kuss, D. J., Griffiths, M. D., Karila, L., \& Billieux, J. (2014). Internet addiction: A systematic review of epidemiological research for the last decade. Current Pharmaceutical Design, 20(25), 4026-4052. doi:10.2174/13816128113199990617

Lader, D., Short, S., \& Gershuny, J. (2006). The time use survey 2005. Retrieved March 20, 2016, from http://www.timeuse. org/sites/ctur/files/public/ctur_report/1905/lader_short_and_ gershuny_2005_kight_diary.pdf

Landers, R. N., \& Lounsbury, J. W. (2006). An investigation of Big Five and narrow personality traits in relation to Internet usage. Computers in Human Behavior, 22(2), 283-293. doi:10. 1016/j.chb.2004.06.001

Lella, A. (2014). Half of millennial Netflix viewers stream video on mobile. ComScore Report. Retrieved March 15, 2016, from http:// www.comscore.com/Insights/Data-Mine/Half-of-MillennialNetflix-Viewers-Stream-Video-on-Mobile

Lemish, D. (1985). Soap opera viewing in college: A naturalistic inquiry. Journal of Broadcasting \& Electronic Media, 29(3), 275-293. doi:10.1080/08838158509386585

Lemmens, J. S., Valkenburg, P. M., \& Peter, J. (2011). Psychosocial causes and consequences of pathological gaming. Computers in Human Behavior, 27(1), 144-152. doi:10.1016/j.chb. 2010.07.015

Levy, M. R., \& Windahl, S. (1985). The concept of audience activity. In K. E. Rosengren, L. A. Wenner \& P. Palmgreen (Eds.), Media gratifications research: Current perspectives 
(pp. 109-122). Beverly Hills, CA: Sage. (as cited in Godlewski \& Perse, 2010)

Lisanti, J. (2012). TV cord-cutting on the rise. Variety. Retrieved March 20, 2016, from http://variety.com/2012/digital/news/tvcord-cutting-on-the-rise-1118050431/

Livingstone, S. M. (1988). Why people watch soap opera: An analysis of the explanations of British viewers. European Journal of Communication, 3(1), 55-80. doi:10.1177/026732 3188003001004

Magid, L. (2013). Households abandoning cable and satellite for streaming. Forbes. Retrieved March 20, 2016, from http:/www.forbes.com/sites/larrymagid/2013/03/19/householdsabandoning-cable-and-satellite-for-streaming/\#7e 7552b4109a

Maráz, A., Király, O., \& Demetrovics, Z. (2015). Commentary on: Are we overpathologizing everyday life? A tenable blueprint for behavioral addiction research: The diagnostic pitfalls of surveys: If you score positive on a test of addiction, you still have a good chance not to be addicted. Journal of Behavioral Addictions, 4(3), 151-154. doi:10.1556/2006.4.2015.026

Marsh, H. W., Hau, K.-T., \& Grayson, D. (2005). Goodness of fit evaluation in structural equation modeling. In A. MaydeuOlivares \& J. McArdle (Eds.), Contemporary psychometrics. A Festschrift for Roderick P. McDonald. Mahwah, NJ: Erlbaum.

Marsh, H. W., \& Hocevar, D. (1985). Application of confirmatory factor analysis to the study of self-concept: First- and higher order factor models and their invariance across groups. Psychological Bulletin, 97(3), 562-582. doi:10.1037/0033-2909. 97.3.562

Marsh, H. W., Lüdtke, O., Muthén, B., Asparouhov, T., Morin, A. J. S., Trautwein, U., \& Nagengast, B. (2010). A new look at the big five factor structure through exploratory structural equation modeling. Psychological Assessment, 22(3), 471491. doi:10.1037/a0019227

Marsh, H. W., Morin, A. J. S., Parker, P. D., \& Kaur, G. (2014). Exploratory structural equation modeling: An integration of the best features of exploratory and confirmatory factor analysis. Annual Review of Clinical Psychology, 10(1), 85-110. doi:10.1146/annurev-clinpsy-032813-153700

Mazhari, S. (2012). Association between problematic Internet use and impulse control disorders among Iranian university students. Cyberpsychology, Behavior, and Social Networking, 15(5), 270-273. doi:10.1089/cyber.2011.0548

McDonald, R. P. (1970). Theoretical foundations of principal factor analysis, canonical factor analysis, and alpha factor analysis. British Journal of Mathematical \& Statistical Psychology, 23(1), 1-21. doi:10.1111/j.2044-8317.1970.tb00432.x

Mentzoni, R. A., Brunborg, G. S., Molde, H., Myrseth, H., Skouverøe, K. J. M., Hetland, J., \& Pallesen, S. (2011). Problematic video game use: Estimated prevalence and associations with mental and physical health. Cyberpsychology, Behavior, and Social Networking, 14(10), 591-596. doi:10. 1089/cyber.2010.0260

Meredith, W. (1993). Measurement invariance, factor analysis and factorial invariance. Psychometrika, 58(4), 525-543. doi:10. 1007/BF02294825

Milfont, T. L., \& Fischer, R. (2010). Testing measurement invariance across groups: Applications in cross-cultural research. International Journal of Psychological Research, 3(1), 111130. doi: $10.21500 / 20112084.857$

Morin, A. J. S., Marsh, H. W., \& Nagengast, B. (2013). Exploratory structural equation modeling. In G. R. Hancock \&
R. O. Mueller (Eds.), Structural equation modeling: A second course (pp. 395-436). Charlotte, NC: Information Age.

Muthén, L. K., \& Muthén, B. O. (1998-2015). Mplus user's guide (7th ed.). Los Angeles, CA: Muthén \& Muthén.

Netflix Media Center. (2016). Netflix is now available around the World. Retrieved March 7, 2016, from https://media. netflix.com/en/press-releases/netflix-is-now-available-around-theworld

Nunnally, J. C. (1978). Psychometric theory (2nd ed.). New York, NY: McGraw-Hill.

Orosz, G., Bőthe, B., \& Tóth-Király, I. (2016). The development of the Problematic Series Watching Scale (PSWS). Journal of Behavioral Addictions, 5(1), 144-150. doi:10.1556/2006.5. 2016.011

Orosz, G., Tóth-Király, I., \& Bőthe, B. (2016). Four facets of Facebook intensity - The development of the Multidimensional Facebook Intensity Scale. Personality and Individual Differences, 100, 95-104. doi:10.1016/j.paid.2015.11.038

Orosz, G., Vallerand, R. J., Bőthe, B., Tóth-Király, I., \& Paskuj, B. (2016). On the correlates of passion for screen-based behaviors: The case of impulsivity and the problematic and nonproblematic Facebook use and TV series watching. Personality and Individual Differences, 101, 167-176. doi:10.1016/j.paid. 2016.05.368

Perse, E. M. (1986). Soap opera viewing patterns of college students and cultivation. Journal of Broadcasting \& Electronic Media, 30(2), 175-193. doi:10.1080/08838158609386618

Perse, E. M. (1990). Audience selectivity and involvement in the newer media environment. Communication Research, 17(5), 675-697. doi:10.1177/009365090017005005

Perse, E. M., \& Rubin, A. M. (1990). Chronic loneliness and television use. Journal of Broadcasting \& Electronic Media, 34(1), 37-53. doi:10.1080/08838159009386724

Peters, C. S., \& Malesky, L. A. (2008). Problematic usage among highly-engaged players of massively multiplayer online role playing games. CyberPsychology \& Behavior, 11(4), 481-484. doi:10.1089/cpb.2007.0140

Pontes, H. M., Szabó, A., \& Griffiths, M. D. (2015). The impact of Internet-based specific activities on the perceptions of Internet addiction, quality of life, and excessive usage: A cross-sectional study. Addictive Behaviors Reports, 1, 19-25. doi:10.1016/ j.abrep.2015.03.002

PR Newswire. (2013). Netflix declares binge watching is the new normal. Retrieved February 16, 2016, from http://www. prnewswire.com/news-releases/netflix-declares-binge-watching-is-the-new-normal-235713431.html

Purcell, K. (2010). The state of online video. Washington, DC: Pew Research Center. Retrieved March 20, 2016, from http://www. pewinternet.org/2010/06/03/the-state-of-online-video/

Rubin, A. M. (1977). Television usage, attitudes and viewing behaviors of children and adolescents. Journal of Broadcasting \& Electronic Media, 21(3), 355-369. doi:10.1080/0883815 7709363844

Rubin, A. M. (1979). Television use by children and adolescents. Human Communication Research, 5(2), 109-120. doi:10.1111/ j.1468-2958.1979.tb00626.x

Rubin, A. M. (1985). Uses of daytime television soap operas by college students. Journal of Broadcasting \& Electronic Media, 29(3), 241-258. doi:10.1080/08838158509386583

Rubin, A. M., \& Perse, E. M. (1987). Audience activity and soap opera involvement a uses and effects investigation. Human 
Communication Research, 14(2), 246-268. doi:10.1111/j. 1468-2958.1987.tb00129.x

Ryan, R. M., \& Deci, E. L. (2017). Self-determination theory. Basic psychological needs in motivation, development, and wellness. New York, NY: Guildford Press.

Ryan, T., \& Xenos, S. (2011). Who uses Facebook? An investigation into the relationship between the Big Five, shyness, narcissism, loneliness, and Facebook usage. Computers in Human Behavior, 27(5), 1658-1664. doi:10.1016/j.chb.2011. 02.004

Series. (n.d.). Merriam-Webster. Retrieved on March 6, 2016, from http://www.merriam-webster.com/dictionary/series

Sijtsma, K. (2009). On the use, the misuse, and the very limited usefulness of Cronbach's alpha. Psychometrika, 74(1), 107120. doi:10.1007/s11336-008-9101-0

Skoric, M. M., Teo, L. L. C., \& Neo, R. L. (2009). Children and video games: Addiction, engagement, and scholastic achievement. Cyberpsychology \& Behavior, 12(5), 567-572. doi:10. 1089/cpb.2009.0079

Smith, C. (2015). By the numbers: 50 amazing netflix statistics and facts. Retrieved March 20, 2016, from http://expandedramblings.com/index.php/netflix_statistics-facts/

Soap Opera. (n.d.). Merriam-Webster. Retrieved March 15, 2016, from http://www.merriam-webster.com/dictionary/soap opera

Starcevic, V., Berle, D., Porter, G., \& Fenech, P. (2011). Problem video game use and dimensions of psychopathology. International Journal of Mental Health and Addiction, 9(3), 248-256. doi:10.1007/s11469-010-9282-5

Statistics Canada. (2011). General social survey 2010 - Overview of the time use of Canadians. Retrieved March 28, 2016 , from http://www.statcan.gc.ca/pub/89-647-x/89-647-x2011001eng.pdf

Statistics New Zealand. (2011). Time use survey: 2009/2010. Retrieved March 20, 2016, from http://www.stats.govt.nz browse_for_stats/people_and_communities/time_use/Time UseSurvey_HOTP2009-10/List\%20of\%20tables.aspx

Tóth-Király, I., Bőthe, B., \& Orosz, G. (2017). Exploratory structural equation modeling analysis of the Self-Compassion Scale. Mindfulness, 8(4), 881-892. doi:10.1007/s12671-016-0662-1

Tóth-Király, I., Bőthe, B., Rigó, A., \& Orosz, G. (2017). An illustration of the exploratory structural equation modeling (ESEM) framework on the passion scale. Frontiers in Psychology, 8, 1968. doi:10.3389/fpsyg.2017.01968

Tóth-Király, I., Morin, A. J. S., Bőthe, B., Orosz, G., \& Rigó, A. (2017). Investigating the multidimensionality of need fulfillment: A bifactor exploratory structural equation modeling representation. Structural Equation Modeling. Advance online publication. doi:10.1080/10705511.2017.1374867

Tóth-Király, I., Orosz, G., Dombi, E., Jagodics, B., Farkas, D., \& Amoura, C. (2017). Cross-cultural comparative examination of the Academic Motivation Scale using exploratory structural equation modeling. Personality and Individual Differences, 106, 130-135. doi:10.1016/j.paid.2016.10.048

Twohig, M. P., Crosby, J. M., \& Cox, J. M. (2009). Viewing Internet pornography: For whom is it problematic, how, and why? Sexual Addiction \& Compulsivity, 16(4), 253-266. doi:10.1080/10720160903300788

US Department of Labor. (2015). American Time Use Survey 2014 results. Retrieved February 29, 2016, from http://www. bls.gov/news.release/pdf/atus.pdf

Vallerand, R. J. (2015). The psychology of passion: A dualistic model. New York, NY: Oxford University Press.

Van der Aa, N., Overbeek, G., Engels, R. C., Scholte, R. H., Meerkerk, G. J., \& Van den Eijnden, R. J. (2009). Daily and compulsive Internet use and well-being in adolescence: A diathesis-stress model based on big five personality traits. Journal of Youth and Adolescence, 38(6), 765-776. doi:10. 1007/s10964-008-9298-3

Vandenberg, R. J. (2002). Toward a further understanding of and improvement in measurement invariance methods and procedures. Organizational Research Methods, 5(2), 139-158. doi:10.1177/1094428102005002001

Vandenberg, R. J., \& Lance, C. E. (2000). A review and synthesis of the measurement invariance literature: Suggestions, practices, and recommendations for organizational research. Organizational Research Methods, 3(1), 4-70. doi:10.1177/10944 2810031002

Wang, L., Luo, J., Bai, Y., Kong, J., Luo, J., Gao, W., \& Sun, X. (2013). Internet addiction of adolescents in China: Prevalence, predictors, and association with well-being. Addiction Research \& Theory, 21(1), 62-69. doi:10.3109/16066359. 2012.690053

Whetmore, E. J., \& Kielwasser, A. P. (1983). The soap opera audience speaks: A preliminary report. Journal of American Culture, 6(3), 110-116. doi:10.1111/j.1542-734X.1983.0603_ 110.X

Yau, Y. H., Potenza, M. N., \& White, M. A. (2013). Problematic Internet use, mental health and impulse control in an online survey of adults. Journal of Behavioral Addictions, 2(2), 72 81. doi:10.1556/JBA.1.2012.015 


\section{APPENDIX 1A. THE ENGLISH VERSION OF THE SERIES WATCHING ENGAGEMENT SCALE}

In the following, you are going to read items related to series watching. For each statement, please indicate your answer on the following scale:

\begin{tabular}{lcccccc}
\hline 1 & 2 & 3 & 4 & 5 & 6 & 7 \\
\hline $\begin{array}{l}\text { Not true to me at } \\
\text { all. }\end{array}$ & $\begin{array}{c}\text { Not true to } \\
\text { me. }\end{array}$ & $\begin{array}{c}\text { Rather not true to } \\
\text { me. }\end{array}$ & $\begin{array}{c}\text { Neither true, nor untrue } \\
\text { to me. }\end{array}$ & $\begin{array}{c}\text { Rather true to } \\
\text { me. }\end{array}$ & $\begin{array}{c}\text { True to } \\
\text { me. }\end{array}$ & $\begin{array}{c}\text { Completely true to } \\
\text { me. }\end{array}$ \\
\hline
\end{tabular}

\begin{tabular}{|c|c|c|c|c|c|c|c|}
\hline & 1 & 2 & 3 & 4 & 5 & 6 & 7 \\
\hline 1. Watching series motivates me to learn foreign languages. & $\mathrm{O}$ & $\mathrm{O}$ & $\mathrm{O}$ & $\mathrm{O}$ & $\mathrm{O}$ & $\mathrm{O}$ & $\mathrm{O}$ \\
\hline 2. During series watching, I have recognized one of my life situations. & $\mathrm{O}$ & $\mathrm{O}$ & $\mathrm{O}$ & $\mathrm{O}$ & $\mathrm{O}$ & $\mathrm{O}$ & $\mathrm{O}$ \\
\hline 3. I spend more time watching series than I would like to. & $\mathrm{O}$ & $\mathrm{O}$ & $\mathrm{O}$ & $\mathrm{O}$ & $\mathrm{O}$ & $\mathrm{O}$ & $\mathrm{O}$ \\
\hline 4. After a series has completely ended I can hardly concentrate on other things. & $\mathrm{O}$ & $\mathrm{O}$ & $\mathrm{O}$ & $\mathrm{O}$ & $\mathrm{O}$ & $\mathrm{O}$ & $\mathrm{O}$ \\
\hline 5. I talk about series with my family. & $\mathrm{O}$ & $\mathrm{O}$ & $\mathrm{O}$ & $\mathrm{O}$ & $\mathrm{O}$ & $\mathrm{O}$ & $\mathrm{O}$ \\
\hline 6. Series watching improved my language skills. & $\mathrm{O}$ & $\mathrm{O}$ & $\mathrm{O}$ & $\mathrm{O}$ & $\mathrm{O}$ & $\mathrm{O}$ & $\mathrm{O}$ \\
\hline 7. In the series I watch, characters are in life situations similar to mine. & $\mathrm{O}$ & $\mathrm{O}$ & $\mathrm{O}$ & $\mathrm{O}$ & $\mathrm{O}$ & $\mathrm{O}$ & $\mathrm{O}$ \\
\hline 8. I watch series even when I already should sleep. & $\mathrm{O}$ & $\mathrm{O}$ & $\mathrm{O}$ & $\mathrm{O}$ & $\mathrm{O}$ & $\mathrm{O}$ & $\mathrm{O}$ \\
\hline 9. After a series has ended, I feel emptiness inside me. & $\mathrm{O}$ & $\mathrm{O}$ & $\mathrm{O}$ & $\mathrm{O}$ & $\mathrm{O}$ & $\mathrm{O}$ & $\mathrm{O}$ \\
\hline 10. Series are often discussed topics at my workplace/school. & $\mathrm{O}$ & $\mathrm{O}$ & $\mathrm{O}$ & $\mathrm{O}$ & $\mathrm{O}$ & $\mathrm{O}$ & $\mathrm{O}$ \\
\hline 11. Language learning motives me to watch series. & $\mathrm{O}$ & $\mathrm{O}$ & $\mathrm{O}$ & $\mathrm{O}$ & $\mathrm{O}$ & $\mathrm{O}$ & $\mathrm{O}$ \\
\hline $\begin{array}{l}\text { 12. While watching TV series, I sometimes feel like the same situations happen in my life like in the } \\
\text { characters'. }\end{array}$ & $\mathrm{O}$ & $\mathrm{O}$ & $\mathrm{O}$ & $\mathrm{O}$ & $\mathrm{O}$ & $\mathrm{O}$ & $\mathrm{O}$ \\
\hline 13. I watch too many episodes of series in a row. & $\mathrm{O}$ & $\mathrm{O}$ & $\mathrm{O}$ & $\mathrm{O}$ & $\mathrm{O}$ & $\mathrm{O}$ & $\mathrm{O}$ \\
\hline 14. I can hardly take my mind off a completely ended series. & $\mathrm{O}$ & $\mathrm{O}$ & $\mathrm{O}$ & $\mathrm{O}$ & $\mathrm{O}$ & $\mathrm{O}$ & $\mathrm{O}$ \\
\hline 15. I discuss what's going on in series with my acquaintances. & $\mathrm{O}$ & $\mathrm{O}$ & $\mathrm{O}$ & $\mathrm{O}$ & $\mathrm{O}$ & $\mathrm{O}$ & $\mathrm{O}$ \\
\hline
\end{tabular}

Key

Self-development: $1,6,11$

Identification: $2,7,12$

Overuse: $3,8,13$

Persistence: $4,9,14$

Social interaction: $5,10,15$ 


\section{APPENDIX 1B. THE HUNGARIAN VERSION OF THE SERIES WATCHING ENGAGEMENT SCALE}

A következőkben sorozatnézéssel kapcsolatos tételeket olvashatsz. Kérjük, jelöld az alábbi hétfokozatú skálán, hogy mennyire igazak rád az alábbi állítások!

\begin{tabular}{lcccccc}
\hline 1 & 2 & 3 & 4 & 5 & 6 & 7 \\
\hline $\begin{array}{l}\text { Egyáltalán nem igaz } \\
\text { rám }\end{array}$ & $\begin{array}{c}\text { Nem igaz } \\
\text { rám. }\end{array}$ & $\begin{array}{c}\text { Inkább nem igaz } \\
\text { rám. }\end{array}$ & $\begin{array}{c}\text { Igaz is rám, meg nem } \\
\text { is. }\end{array}$ & $\begin{array}{c}\text { Inkább igaz } \\
\text { rám. }\end{array}$ & $\begin{array}{c}\text { Igaz } \\
\text { rám. }\end{array}$ & $\begin{array}{c}\text { Teljesen igaz } \\
\text { rám. }\end{array}$ \\
\hline
\end{tabular}

\begin{tabular}{|c|c|c|c|c|c|c|c|}
\hline & 1 & 2 & 3 & 4 & 5 & 6 & 7 \\
\hline 1. A sorozatnézés motivál a nyelvtanulásra. & $\mathrm{O}$ & $\mathrm{O}$ & $\mathrm{O}$ & $\mathrm{O}$ & $\mathrm{O}$ & $\mathrm{O}$ & $\mathrm{O}$ \\
\hline 2. Sorozatnézés közben ráismertem egy saját élethelyzetemre. & $\mathrm{O}$ & $\mathrm{O}$ & $\mathrm{O}$ & $\mathrm{O}$ & $\mathrm{O}$ & $\mathrm{O}$ & $\mathrm{O}$ \\
\hline 3. Több időt töltök sorozatnézéssel, mint amennyit szeretnék. & $\mathrm{O}$ & $\mathrm{O}$ & $\mathrm{O}$ & $\mathrm{O}$ & $\mathrm{O}$ & $\mathrm{O}$ & $\mathrm{O}$ \\
\hline 4. Miután egy sorozat teljesen véget ér, nehezen tudok másra koncentrálni. & $\mathrm{O}$ & $\mathrm{O}$ & $\mathrm{O}$ & $\mathrm{O}$ & $\mathrm{O}$ & $\mathrm{O}$ & $\mathrm{O}$ \\
\hline 5. A családommal beszélgetek a sorozatokról. & $\mathrm{O}$ & $\mathrm{O}$ & $\mathrm{O}$ & $\mathrm{O}$ & $\mathrm{O}$ & $\mathrm{O}$ & $\mathrm{O}$ \\
\hline 6. A sorozatnézéssel fejlődött a nyelvtudásom. & $\mathrm{O}$ & $\mathrm{O}$ & $\mathrm{O}$ & $\mathrm{O}$ & $\mathrm{O}$ & $\mathrm{O}$ & $\mathrm{O}$ \\
\hline 7. A sorozatokban, amelyeket nézek, a szereplók hozzám hasonló élethelyzetben vannak. & $\mathrm{O}$ & $\mathrm{O}$ & $\mathrm{O}$ & $\mathrm{O}$ & $\mathrm{O}$ & $\mathrm{O}$ & $\mathrm{O}$ \\
\hline 8. Még akkor is sorozatot nézek, amikor már aludnom kellene. & $\mathrm{O}$ & $\mathrm{O}$ & $\mathrm{O}$ & $\mathrm{O}$ & $\mathrm{O}$ & $\mathrm{O}$ & $\mathrm{O}$ \\
\hline 9. Egy sorozat végeztével ûrt érzek magamban. & $\mathrm{O}$ & $\mathrm{O}$ & $\mathrm{O}$ & $\mathrm{O}$ & $\mathrm{O}$ & $\mathrm{O}$ & $\mathrm{O}$ \\
\hline 10. A sorozat gyakori beszédtéma a munkahelyemen/iskolában. & $\mathrm{O}$ & $\mathrm{O}$ & $\mathrm{O}$ & $\mathrm{O}$ & $\mathrm{O}$ & $\mathrm{O}$ & $\mathrm{O}$ \\
\hline 11. Motivál a nyelvtanulás arra, hogy sorozatot nézzek. & $\mathrm{O}$ & $\mathrm{O}$ & $\mathrm{O}$ & $\mathrm{O}$ & $\mathrm{O}$ & $\mathrm{O}$ & $\mathrm{O}$ \\
\hline 12. Sorozatnézés közben néha úgy érzem, hogy az történik az én életemben is, mint a szereplőkében. & $\mathrm{O}$ & $\mathrm{O}$ & $\mathrm{O}$ & $\mathrm{O}$ & $\mathrm{O}$ & $\mathrm{O}$ & $\mathrm{O}$ \\
\hline 13. Túl sok sorozatrészt nézek meg egymás után. & $\mathrm{O}$ & $\mathrm{O}$ & $\mathrm{O}$ & $\mathrm{O}$ & $\mathrm{O}$ & $\mathrm{O}$ & $\mathrm{O}$ \\
\hline 14. Nehezen tudom elszakítani a gondolataimat egy végleg befejezett sorozatról. & $\mathrm{O}$ & $\mathrm{O}$ & $\mathrm{O}$ & $\mathrm{O}$ & $\mathrm{O}$ & $\mathrm{O}$ & $\mathrm{O}$ \\
\hline 15. Az ismerőseimmel szoktunk beszélgetni arról, hogy éppen mi történik egy sorozatban. & $\mathrm{O}$ & $\mathrm{O}$ & $\mathrm{O}$ & $\mathrm{O}$ & $\mathrm{O}$ & $\mathrm{O}$ & $\mathrm{O}$ \\
\hline
\end{tabular}

\section{Kiértékelő-kulcs}

Önfejlesztés: 1, 6, 11

Identifikáció: 2, 7, 12

Túlhasználat: $3,8,13$

Ragaszkodás: 4, 9, 14

Társas interakció: 5, 10, 15 